http://ejournal.ihdn.ac.id

\title{
LONTAR TARU PRAMANA: PELESTARIAN BUDAYA PENGOBATAN TRADISIONAL BALI
}

\author{
Putu Eka Sura Adnyana \\ Karyasiswa Pascasarjana IHDN Denpasar \\ Email: ekasura@gmail.com
}

\begin{abstract}
Abstrak
Lontar Taru Pramana menguraikan obat-obatan alternatif dengan bahan tumbuh-tumbuhan. Disamping itu Lontar Taru Pramana bermanfaat untuk kesehatan. Pengobatan dengan obat berdasarkan Lontar Taru Pramana sangat murah karena tidak banyak mengeluarkan biaya, terjangkau bagi seluruh kalangan masyarakat. Bahan-bahan obat dapat diambil dari alam diramu secara mudah. Disamping itu meningkatnya obat alternatif memanfaatkan tumbuhtumbuhan secara tidak langsung akan melestarikan tumbuhan-tumbuhan itu, dengan lestarinya tumbuhan-tumbuhan maka pelestarian lingkungan sebagai sumber kesehatan mahluk hidup akan meningkat, sebagaimana progam dari pemerintah. Ajaran pengobatan Taru Pramana, bahwa dalam Lontar Taru Pramana menjelaskan mitologi tumbuh-tumbuhan itu dapat berbicara dan menceritakan khasiat dirinya. Setiap tumbuh-tumbuhan menyatakan dirinya dapat menyembuhkan suatu penyakit tertentu, baik dengan daunnya bunganya, buahnya, kulitnya, akarnya, bahkan kayunya. Fungsi Tumbuh-Tumbuhan Sebagai Bahan Pengobatan, disebutkan bahwa dalam Taru Pramana semua tumbuh-tumbuhan menyatakan dirinya dapat dijadikan obat ketika ia dicampur dengan tumbuh-tumbuhan yang lainnya dengan presentase tertentu. Setiap campuran ada dengan cara dihaluskan kemudian ditambah dengan air lalu diminum dipakaikan jamu. Adapun tujuan pelestarian tumbuhtumbuhan disamping sebagai bahan obat adalah juga menjaga keseimbangan ekosistem dalam kehidupan serta melestarikan keanekaragaman hayati yang bermanfaat bagi ilmu pengetahuan dan masyarakat.
\end{abstract}

Kata Kunci: Lontar Taru Pramana, Budaya, Pengobatan Tradisional Bali 


\section{PENDAHULUAN}

Karya klasik Indonesia mengandung nilainilai yang sangat penting dan berharga sebagai warisan rohani Bangsa Indonesia. Nilai-nilai kearifan tersebut merupakan perbendaharaan pikiran dan cita-cita nenek moyang yang dahulu menjadi pedoman kehidupan mereka dan diutamakan (Robson, 1978: 5-6). Kearifan tersebut yang menyebabkan Sastra Jawa Kuno yang banyak mengandung nilai-nilai kehidupan tetap masih digandrungi di Bali. Bahkan dalam praktek keseharian Sastra Jawa Kuno hidup berdampingan dengan kebudayaan, dan ritus keagamaan HinduBali. Mastuti dalam Suastika dkk. (2012: 10), menuturkan di Balilah kebudayaan Jawa Kuno berpengaruh besar di luar Jawa sendiri. Pulau Bali tidak pernah secara keseluruhan di Jawa-kan namun terus berkembang tipe kebudayaan Hindunya sendiri, yang tidak seperti kebudayaan Jawa.

Perkembangan sastra di Bali tidak dapat dilepaskan dari faktor sejarah kesusastraan klasik selama kurun waktu antara abad ke-9 sampai dengan ke-15 di Jawa. Selama kurun waktu itu di Jawa Tengah dan Timur terjadi proses penciptaan karya-karya sastra klasik (Jawa Kuna) secara besar-besaran yang dilakukan oleh para pujangga istana (para kawi) baik karya sastra dalam bentuk prosa (parwa) maupun puisi (kakawin).

Keraton-keraton di Bali menjadi penjaga setia Kesusastraan Jawa Kuno. Di kalangan brahmana dan istana, karya-karya Sastra Jawa Kuno tetap dibaca, dipelajari, disalin kembali bahkan diciptakan kembali. Masyarakat Bali terus mengembangkan Sastra Jawa Kuno yang disebutnya sebagai Sastra Kawi. Kegiatan olah sastra tersebut mencapai puncaknya pada masa Kerajaan Gelgel pada abad ke-16 (Suarka dkk, 2005: 1). Selaras dengan hal tersebut maka Bali merupakan tempat penyelamat dan sekaligus penyimpanan ribuan naskah lama dalam bentuk lontar. Naskah lontar itu ada yang merupakan koleksi pribadi, kelompok maupun lembaga. Dalam Haryati (1991: 1) menyebutkan bahwa isi suatu naskah bisa saja meliputi segala aspek kehidupan bangsa, misalnya filsafat, agama, kepercayaan, teknologi, sosial, pengobatan dan hal-hal lain yang menyangkut keperluan hidup bangsa secara menyeluruh. Nilai-nilai luhur yang dikandung kesusastraan Jawa Kuno mampu memberikan refleksi untuk mengatasi permasalahan-permasalah dari berbagai bidang kehidupan.

Salah satunya dalam sistem pengobatan tradisional di Bali yang ditemukan di dalam teks Usada Taru Pramana. Usada Taru Pramana adalah salah satu lontar dari sekian jumlah Lontar Usada yang terdapat pada masyarakat, serta paling populer dikalangan masyarakat Bali. Kata Taru memiliki arti pohon dan Pramana memiliki arti Kekuasaan, kedaulatan. Secara harfiah dapat diartikan Taru Pramana adalah suatu pohon atau tumbuhan yang memiliki kekuatan sebagai obat.

Jika ditelusuri lebih lanjut bahwa Lontar Taru Pramana ini memiliki keunikan tertentu, dalam mitologinya merupakan dialog antara $\mathrm{Mpu}$ Kuturan dan tumbuh-tumbuhan yang berkhasiat obat. Mpu Kuturan menjadi dukun yang tersohor dan sidhi dalam pengobatan, tiba masa suramnya orang yang diobati tidak dapat disembuhkan dan meninggal satupun tidak dapat disembuhkan sehingga Mpu Kuturan pergi untuk bertapa atau bersemadi di kuburan di atas tempat pembakaran mayat selama 1 bulan 7 hari ditemani oleh adiknya Punggung Tiwas. Dalam pertapaan tersebut mendapatkan anugrah dari Dewa Sad Kahyangan (Dewa rudra). Itu sebabnya beliau tau nama-nama kayu sehingga Mpu Kuturan dijuluki Taru Lata Tranagulma. Pertama datang kayu bringin bertanya kepada Mpu Kuturan kenapa Tuhanku bersedih hati dan memanggil saya. Kemudian Mpu Kuturan menjawab aku menjadi dukun tidak mampu menyembuhkan sehingga aku kesini bertapa untuk menanyakan kesemua pohon kayu apa kegunaannya atau khasiatnya dan dipakai obat apa. Kemudian pohon bringin pergi dan kemudian datang pohon-pohon silih berganti menyebutkan dirinya memiliki kelebihan untuk pengobatan penyakit-penyakit tertentu dengan tanaman lain sebagai pelengkap agar berkasihat lebih maksimum.

Peneliti tertarik meneliti Lontar Taru 
Pramana karena didalamnya menguraikan banyak obat-obatan alternatif dengan bahan tumbuhtumbuhan. Disamping itu dengan adanya Lontar Taru Pramana ini sangat bermanfaat untuk kesehatan karena tidak terlalu banyak dalam mengeluarkan biaya, terjangkau bagi seluruh kalangan masyarakat, dengan meningkatnya obat alternatif memanfaatkan tumbuh-tumbuhan dialam semesta maka secara tidak langsung akan melestarikan tumbuhan-tumbuhan itu, dengan lestarinya tumbuhan-tumbuhan itu maka pelestarian lingkungan sebagai sumber kesehatan mahluk hidup akan meningkat, sebagaimana progam dari pemerintah.

\section{PEMBAHASAN \\ Lontar Taru Pramana}

Lontar adalah sebuah teks yang berisikan purana sebagai bagian dari Weda smerti khususnya dalam kelompok Upaweda sebagai kitab suci umat Hindu Dharma yang disebutkan tidak akan pernah musnah selama kehidupan ini masih eksis. Lontar juga disebutkan adalah salah satu bentuk naskah kuno (manuskrip) nusantara yang banyak ditemukan di pulau Bali. Penjelasan ini dijelaskan pula oleh Zoetmulder (1985:100) bahwa naskah zaman Jawa Kuna berupa lontar dari pohon tal, kemudian muncul kata siwalan, sawala, suwala, sawala, patra, sewala patra, dan siwalan yang dipergunakan untuk arti semua surat, yang juga menunjukkan pohon tal itu.

Taru Pramana berasal dari kata taru memiliki arti pohon, kayu atau tumbuhan, dan kata Pramana memiliki arti kekuasaan, kedaulatan (Warsito, 1985:264). Secara harfiah dapat diartikan Taru Pramana adalah suatu pohon atau tumbuhan yang memiliki kekuatan dan fungsi sebagai obat. Lontar Taru Pramana dalam penelitian ini adalah naskah kuno nusantara yang menguraikan tentang tumbuh-tumbuhan sebagai sarana dan bahan obatobatan.

\section{Pelestarian Budaya}

Menurut Kamus Besar Bahasa Indonesia (KBBI) pelestarian berasal dari kata lestari yang berarti tetap seperti keadaannya semula; tidak berubah; bertahan; kekal. Kemudian kata lestari mendapat imbuhan berupa awalan pe- dan akhiran -an sehingga menjadi pelestarian, dimana pelestarian berarti proses, cara, perbuatan melestarikan; perlindungan dari kemusnahan atau kerusakan. Dalam kaitannya dengan penelitian ini pelestarian dimaksudkan untuk mempertahankan, menjaga, melindungi budaya.

Kata budaya diambil dari bahasa Sansekerta yakni 'buddhayah'. Kata ini memiliki arti bahwa segala sesuatu yang ada hubungannya dengan akal serta budi manusia. Sedangkan secara harfiah, budaya merupakan cara hidup yang digunakan sekelompok masyarakat yang diturunkan dari generasi sebelumnya kepada generasi berikutnya. Jadi dapat disimpulkan bahwa pelestarian budaya adalah mempertahankan dan melindungi segala sesuatu yang berhubungan dengan akal serta budi manusia, dalam tradisi pengobatan tradisional Bali. Mengenai pelestarian budaya, Ranjabar (2006:114) mengemukakan bahwa pelestarian norma lama bangsa (budaya lokal) adalah mempertahankan nilai-nilai seni budaya, nilai tradisional dengan mengembangkan perwujudan yang bersifat dinamis, serta menyesuaikan dengan situasi dan kondisi yang selalu berubah dan berkembang. Pelestarian budaya dalam penelitian ini adalah mempertahanan pengobatan tradisional dengan sarana tumbuhtumbuhan dalam Lontar Taru Pramana.

Menurut BPOM, pengertian pengobatan tradisional berdasarkan Peraturan Menteri kesehatan Nomor 246/Menkes/Per/V/1990 Pasal 1 (diakses hari Rabu, 1 Februari 2017) menyebutkan bahwa pengobatan tradisional adalah pengobatan atau penyembuhan menggunakan bahan atau ramuan bahan yang berupa bahan tumbuhan, bahan hewan, bahan mineral, sediaan galenik atau campuran dan bahan-bahan tersebut, yang secara traditisional telah digunakan untuk pengobatan berdasarkan pengalaman. Pengobatan tradisional dalam penelitian ini adalah pengobatan dengan menggunakan sarana tumbuh-tumbuhan yang bersumber dalam naskah kuno yaitu Lontar Taru Pramana. 


\section{Ajaran Pengobatan Taru Pramana}

Penggunaan tanaman sebagai pengobatan herbal sudah dipraktekkan sejak jaman dahulu. Sebelum adanya pengobatan modern seperti saat ini tumbuh-tumbuhan dimanfaatkan untuk obatobatan dalam kehidupan sehari-hari. Beberapa hasil penelitian membuktikan obat dari tumbuhtumbuhan yang diramu lebih muda dicerna oleh tubuh dan tidak terlalu menyebabkan efek samping. Negara-negara maju saat ini mulai memproduksi obat-obatan dari tanaman herbal.

Berdasarkan uraian diatas salah satu lontar pengobatan yang memanfaatkan tumbuh-tumbuhan sebagai bahan obat adalah Lontar Taru Pramana. Dalam Lontar Taru Pramana secara mitologi tumbuh-tumbuhan itu dapat berbicara dan menceritakan khasiat dirinya. Setiap tumbuhtumbuhan menyatakan dirinya dapat menyembuhkan suatu penyakit tertentu, baik pada daunnya bunganya, buahnya, kulitnya, akarnya, bahkan kayunya. Hal itu dapat dibuktikan dalam kutipan berikut ini;

"...Titiang wit dapdap tis wawu rawuh, babakan titiange dados anggen tamba bengka, rawuhing katumbah bolong 11 besik, uyah areng pinipis, pres saring, tahapakna...".

“...Titiang wit kelor daging tis engket barak nyem, akah panes, dawun titiange dados anggen tamba sakit mata, rawuhing jeruk lengis, uyah areng saring degdegang, tutuh netrania...".

Terjemahannya:

“... Saya ini adalah akar dari pohon dapdap yang dapat menyejukkan, kulit saya dapat dipakai obat perut kembung, dicampur dengan ketumbar 11 biji dicampur dengan garam dilumatkan kemudian diperas airnya dijadikan jamu lalu diminum..."

“... Saya adalah pohon kelor, kulit saya sejuk (tis), getahnya merah yang juga dingin, akar saya panas, daun saya dapat dipakai obat sakit mata dicampur dengan jeruk nipis, dan garam kemudian dilumatkan dan ditambah air, kemudian didiamkan lalu disaring, kemudian dipakai untuk mengobati mata..."

Berdasarkan kutipan diatas, sungguh besar manfaat tumbuh-tumbuhan sebagai obat untuk kesehatan manusia yang tidak menimbulkan efek samping, oleh karena itu keberadaan lontar Taru Pramana perlu disebarluaskan dalam masyarakat sehingga keberadaan tumbuh-tumbuhan perlu dilestarikan dengan cara menanam tumbuhtumbuhan itu minimal dalam pekarangan dalam rumah tangga. Dengan demikian akan dapat melestarikan lingkungan hidup.

\section{Fungsi Tumbuh-Tumbuhan Sebagai Bahan Pengobatan}

Pengetahuan tentang obat dan pengobatan tradisional merupakan salah satu budaya bangsa Indonesia yang perlu dipelihara, dilestarikan dan dikembangkan serta dimanfaatkan dalam upaya meningkatkan derajat kesehatan dan kesejahteraan bangsa. Bangsa Indonesia menyadari bahwa obat dan pengobatan tradisional merupakan bagian integral dan lingkungan sosio-budaya serta mempunyai nilai, karena itu perlu dipertahankan. Dalam Taru Pramana semua tumbuh-tumbuhan menyatakan dirinya dapat dijadikan obat ketika ia dicampur dengan tumbuh-tumbuhan yang lainnya dengan presentase tertentu. Setiap campuran ada yang dihaluskan kemudian ditambah dengan air lalu diminum dipakaikan jamu. Adapula dipakai untuk bedak ketika menyembuhkan kulit. Setiap tumbuh-tumbuhan yang diuraikan dalam Taru Pramana dapat menjadi obat untuk menyembuhkan segala macam penyakit. Seperti dalam kutipan Lontar Taru Pramana dibawah ini:

Iki kaputusan taru pramana, duking hatika hana anama sang prabhu mpu kuturan, amalakun dudukan sira, kuang pira lamin ira, siddha siddhi pwa sira angusadaning, hana pwa masadya mandya bagia, sahananin wang tinamban, de sang prabhu , hana sata hanania, pejah sadaya wetu mageleng ri anggania dewek, las tantunaken dwa, hana inihasa de ya asraya ring setra ulu ring pamuwun, wus agenep salek sapta dina, tumurun, batara ring 
kahyangan, asung hira warah-warah , lamakane sira weruh ing angaraning taru, yan atanya ing ya, apa parania muang gunania sowang-sowang, wus mangkana sang prabhu mpu kuturan teher angarada taru lata, trena gulmapratamia dating, ika pwa wreksa wandira raris umatur, inggih ratu sang prabhu punapi mawinan I ratu maswambawa kadi pamanggeh tur mangesengin kadi titiang. Mangkin ngandika sang prabhu . ih nyen ne iba bingin, wireh awake dadi balian tan sida nyegerang jani makeneh nyekenang nakonang I kayu diri-diri. Apa gunnyane, kenken daging nyane, muang dadi ubad apa, mangkana ujara sang prabhu mpu kuturan . Dadia I taru bingin mapamit wus punika sang prabhu mpu kuturan malih ngarad tan dumada raris rawuh witing :

Terjemahannya:

Inilah yang disebutkan dalam taru pramana, ketika ada seorang raja bernama $\mathrm{Mpu}$ Kuturan, menjalankan pekerjaan sebagai dukun, beberapa lama kemudian, amat berhasillah beliau mengobatin, sangat berbahagialah beliau, semua yang diobati oleh sang raja menjadi sembuh, ada seratus banyaknya semua mati sangat sedihlah beliau dalam dirinya, tidak bisa ditolongnya, lalu beliau bersemedia ditengah-tengah kuburan (pamuwun), setelah mencapai tujuh hari lamanya, turunlah dewa dari khayangan, memberikan nasihat, supaya beliau tahu tentang nama-nama tumbuh-tumbuhan, jika bertanya kepadanya, apa yang menjadi tujuannya dan kegunaannya masingmasing, setelah selesai kemudian raja $\mathrm{Mpu}$ Kuturan memanggil kepada tumbuhtumbuhan melata, rumput yang menjalar semua dating, seperti pohon bringin kemudian bertanya, Oh sang raja apa yang menyebabkan memanggil saya ini. Kemudian menjawablah sang raja, oh siapa kamu ini pohon beringin, saya menjadi dukun tidak dapat menyembuhkan penyakit oleh karena itu saya menanyakan tumbuhan masing-masing, apa kegunaannya, bagaimana isinya dan dapat mengobati penyakit apa. Demikian ucapan sang raja Mpu Kuturan kemudian pohon beringin pergi, lalu sang raja memanggil tumbuhan yang lain..."

Berdasarkan kutipan mitologi tumbuhtumbuhan yang dapat berbicara dalam lontar Taru Pramana berkat anugrah dewa dari kahyangan kepada seorang raja yang bernama Mpu Kuturan sehingga dapat berkomunikasi kepada semua tumbuh-tumbuhan tentang tujuan dan manfaatnya dalam pengobatan segala macam penyakit. Ini memberikan amanat kepada manusia bahwa semua mahluk hidup didunia ini termasuk tumbuhtumbuhan bermanfaat untuk kehidupan. Oleh karena itu sangat diperlukan untuk penelitian tentang manfaat dan pengolahan tumbuh-tumbuhan sebagai bahan obat. Karena itu pelestarian tumbuhtumbuhan sangat penting disamping untuk keharmonisan lingkungan hidup.

Lontar Usada Taru Pramana menyebutkan kasuna (bawang putih) berfungsi untuk membantu dan mengobati beberapa penyakit, seperti: (1) Penyakit Beteg (beri-beri) dapat digunakan dengan bahan seperti: Daun, akar, getah kulit dan Kasuna jangu, mayeh cuka. Kemudian dapat diolah dengan cara dihaluskan, disaring , diminumatau bisa juga menggunakan bahan lain seperti kulit pada pohon Bila, Kasuna jangu, yeh cuka (air cuka) dapat diolah dan digunakan sebagai boreh. (2) Penyakit Puruh (vertigo) dapat diobati dengan bahan-bahan seperi daun pengeng-pengeng dan kasuna jangu, Pengolahannya dengan cara diulig (diratakan dengan halus), kemudian semua bahan lalu tempelkan pada dahi.(3) Penyakit Rangsek (sesak nafas) dapat diobati dengan bahan-bahan seperti Daun Kuanta, Kasuna jangu, temu tis kemudian diolah dengan cara dikunyah halus lalu semburkan pada dada yang sakit. (4) Penyakit Batuk dapat diobati dengan Daun Bunut Bulu, Kasuna jangu, kemudian pengolahannya dapat 
dikunyah halus lalu semburkan di dada.

Demikian juga bawang putih dalam pengobatan berkasihat sebagai antibakteri, antimikotik, dan antioksidan yang telah dibuktikan sengan baik melalui penelitian. Pengambatan penggumpalan trombosit, yang ditingkatkan pada waktu pendarahan dan pembekuan darah disertai peningkatan aktivitas fibriolitik telah diuji secara klinis. Sari pati bawang putih berperan penting dalam penghambatan dalam tahap awal sintesa sterol karena terdapatnya senyawa belerang pada bawang putih (alliin). Indikasinya sebagai pengobatan hiperkolesterolemia, hyperlipidemia, hipertensi ringan, arterosklerosis dan diabetes mellitus. Bila memakannya berlebihan bisa meningkatkan resiko pendaraan pasca operasi (Badan POM RI, 2006:70).

\section{Pelestarian Tumbuh-Tumbuhan}

Pemanfaatan tanaman sebagai obat sudah dari peradaban nenek moyang. Tumbuhan adalah gudang bahan obat yang memiliki banyak manfaat untuk obat berbagai penyakit. Kemampuan meracik tumbuhan berkhasiat obat dan jamu merupakan warisan turun temurun dan mengakar kuat di masyarakat. Tumbuhan yang merupakan bahan baku obat tradisonal tersebut tersebar hampir di seluruh wilayah Indonesia.Tumbuhtumbuhan itu telah dimanfaatkan oleh manusia dalam kehidupan, sejak awal peradaban seperti untuk sandang, pangan, dan papan.

Kebiasaan masyarakat dalam menggunakan obat-obatan alami dilakukan secara turun temurun. Tanaman obat yang biasa digunakan oleh masyarakat untuk mengobati berbagai penyakit di budidayakan atau di tanam sebagai tanaman obat keluarga oleh masyarakat. Hal tersebut merupakan salah satu upaya untuk melestarikan keanekaragaman tanaman yang berpotensi sebagai obat-obatan.

Pengetahuan tentang pemanfaatan tanaman obat merupakan warisan budaya bangsa berdasarkan pengalaman, pengetahuan, dan keterampilan, yang secara turun-temurun telah diwariskan oleh nenek moyang.
Tanaman obat sebagai laboratorium botani sangat diperlukan. Peranan laboratorium botani

sebagai media pendidikan dan penelitian perlu mendapat perhatian khusus dari pemerintah daerah, mengingat masih banyak keanekaragaman hayati yang belum dikaji secara lebih mendalam untuk memberikan manfaat yang besar bagi kesejahteraan hidup.

Berdasarkan uraian diatas pelestarian tumbuh-tumbuhan dapat dilakukan dengan: (1) tidak menebang pohon sembarangan. (2) melakukan tebang pilih artinya menebang dengan memilih ukuran dan usia tumbuhan. (3) penanaman kembali tanaman yang telah dimanfaatkan atau peremajaan tanaman. (4) Pemeliharaan tanaman dengan benar.

Adapun tujuan pelestarian tumbuhtumbuhan, sebagai bahan obat adalah sebagai berikut (1) menjaga keseimbangan ekosistem agar kehidupan dimuka bumi ini tetap berjalan dengan baik. (2) melestarikan keanekaragaman hayati yang bermanfaat bagi ilmu pengetahuan dan masyarakat.(3) menciptakan lingkungan yang nyaman dan mengurangi pencemaran udara dengan tumbuhnya berbagai pohon. (4) dapat dimanfaatkan sebagai tempat hiburan dengan membuat taman rekreasi.

\section{SIMPULAN}

Berdasarkan uraian tersebut di atas maka dapat disimpulkan sebagai berikut: Ajaran Pengobatan Taru Pramana adalah semua tumbuhtumbuhan dapat digunakan sebagai bahan obat untuk menyembuhkan penyakit. Sebagaimana disampaikan dalam Lontar Taru Pramana secara mitologi tumbuh-tumbuhan itu dapat berbicara dan menceritakan khasiat dirinya. Setiap tumbuhtumbuhan menyatakan dirinya dapat menyembuhkan suatu penyakit tertentu, baik pada daunnya bunganya, buahnya, kulitnya, akarnya, bahkan kayunya. Fungsi Tumbuh-Tumbuhan Sebagai Bahan Pengobatan yaitu semua tumbuhtumbuhan dalam Lontar Taru Pramana menyatakan dirinya dapat dipergunakan sebagai bahan obat. Tumbuh-tumbuhan itu menyatakan mulai dari akar, kulit, daun, buah, bunga dan kayunya dapat YOGA DAN KESEHATAN Volume 2, No.2 Desember 20199 
dipakai sebagai obat, ketika dicampur dengan tumbuhan yang lain. Pelestarian TumbuhTumbuhan sebagai bahan obat yang biasa digunakan oleh masyarakat untuk mengobati berbagai penyakit di budidayakan atau ditanam sebagai tanaman obat keluarga oleh masyarakat.

\section{DAFTAR PUSTAKA}

Badan POM. 2006. Pedoman Cara Pembuatan Obat yang Baik. Jakarta.

Duija, I Nengah.2012."Prestise Bahasa Jawa Kuna dalam Adat dan Agama Hindu di Bali", Sastra Jawa Kuna:Refleksi Dulu, Kini, dan Tantangan ke Depan. Ed. I Made Suastika dan I Nyoman Sukartha. Denpasar: Cakra Press

Jirnaya, I Ketut.2011. Usada Budha Kacapi: Teks Sastra Pengobatan Tradisional Masyarakat Bali.Desertasi. Program Pascasarjana Universitas Udayana. Denpasar

Mardiwarsito, L. 1985. Kamus Jawa KunaIndonesia. Ende-Flores: Nusa Indah.

Nala, Ngurah.1991. Usada Kencing Manis. Denpasar: Upada Sastra. . 2006. Aksara Bali dalam Usada. Surabaya: Paramita.

Pulasari, Mangku (2003). Salinan Lontar Taru Pramana. Surabaya: Paramita.

Ranjabar, Jacobus. 2006. Sistem Sosial Budaya Indonesia Suatu Pengantar, Bandung: Ghalia Indonesia.

Robson. 1978. Pengkajian Sastra-sastra Tradisional Indonesia dalam Majalah Bahasa dan Sastra Tahun I No. 8.Jakarta: Pusat Pembinaan dan Pengembangan Bahasa.

Suarka, I Nyoman, I Wayan Suteja. 2005. Kajian

Naskah Lontar Siwagama 2. Denpasar:

Dinas Kebudayaan Provinsi Bali.

Suastika, I Made dan Sukartha I Nyoman. 2012.

Sastra Jawa Kuno: Refleksi Dulu, Kini, dan

Tantangan ke Depan. Denpasar: Cakra

Press.

Suprayoga, Imam dan Tabroni. 2003. Metodologi Penelitian Sosial-Keagamaan, Bandung: Remaja Rusda Karya.

Soebadio, Haryati. 1991 "Relevansi Pernaskahan dengan Berbagai Ilmu" dalam naskah dan Kita, Lembaran Sastra Nomor Khusus 12 Januari 1991 hal 1-14. Depok : FS-UI

Teeuw, A. 1984. Sastra dan Ilmu Sastra Pengantar Teori Sastra. Jakarta: PT Dunia Pustaka Jaya

Wellek, Rene dan Austin Warren. 2014. Teori Kesusastraan Cet. V. Jakarta: Kompas Gramedia Pustaka Utama

Zoetmulder, P.J. 1985. Kalangwan Sastra Jawa Kuna Selayang Pandang Cet.II. Jakarta:Djambatan

Zoetmulder, P.J. dan S.O. Robson. 2011. Kamus Bahasa Jawa Kuno-Indonesia Cet.VI (Diterjemahkan oleh Danusuprapta dan Sumarti Suprayitna). Jakarta: Gramedia Pustaka Utama 